Man and Nature

MAN AND NATURE

L'homme et la nature

\title{
Adam Smith as Rhetorician
}

\section{Ian Ross}

Volume 2, 1984

URI : https://id.erudit.org/iderudit/1011812ar

DOI : https://doi.org/10.7202/1011812ar

Aller au sommaire du numéro

Éditeur(s)

Canadian Society for Eighteenth-Century Studies / Société canadienne d'étude du dix-huitième siècle

ISSN

0824-3298 (imprimé)

1927-8810 (numérique)

Découvrir la revue

Citer cet article

Ross, I. (1984). Adam Smith as Rhetorician. Man and Nature / L'homme et la nature, 2, 61-74. https://doi.org/10.7202/1011812ar
Résumé de l'article

Cette étude donne un aperçu détaillé de la formation rhétorique d'Adam Smith ainsi que de ses activités en tant que professeur de rhétorique en Écosse. Pendant qu'il occupait la Chaire de Logique à l'Université de Glasgow, il a effectué des réformes de curriculum d'une grande importance. Des exemples tirés de ses chefs-d'oeuvre The Theory of Moral Sentiments and The Wealth of Nations font apparaître les traces de sa formation rhétorique dans la structure et dans l'argumentation des deux textes.
Copyright (C Canadian Society for Eighteenth-Century Studies / Société canadienne d'étude du dix-huitième siècle, 1984
Ce document est protégé par la loi sur le droit d'auteur. L'utilisation des services d'Érudit (y compris la reproduction) est assujettie à sa politique d'utilisation que vous pouvez consulter en ligne.

https://apropos.erudit.org/fr/usagers/politique-dutilisation/ 
ADAM SMITH AS RHETORICIAN

Ian Ross

Eyebrows will be raised, perhaps, and jaws dropped at an effort to link Adam Smith with rhetoric. This is a subject long under attack, for we recall the scalpel work of Socrates on the rhetorician Lysias in the dialogue entitled the Phaedrus, composed in long-ago Greece. The inquirer looking into the Index of Ruskin's Stones of Venice (1851-3) will find the bald definition--"a base study"--and following up the entry in the book itself he will read "the study of rhetoric is exclusively for men who desire to deceive or be deceived" (III.ii.xcix). Nevertheless, study of the biographical record shows that rhetoric was at the heart of Smith's secondary education, that he followed up the study at his two Universities of Glasgow and Oxford, was a freelance teacher of it in Edinburgh at the outset of his career, introduced it successfully into the logic course at Glasgow when he became a professor, continued to handle it when translated to the Chair of Moral Philosophy, left a legacy of teaching it to Glasgow University, and put it to use in the composition of his masterworks The Theory of Moral Sentiments (1759) and An Inquiry into the Nature and Causes of the Wealth of Nations (1776), which brought him enduring fame.

Born in 1723, Smith went to Glasgow University in 1737. In the six years before that he probably went through the six classes of the upper part of Kirkcaldy burgh school where there was a notable master, David Miller. ${ }^{1}$ From that time there remain two textbooks with Smith's signature, and one of these, Eutropii Historiae Romanae Breviarum (Edinburgh, 1725), bears the date in his hand, "May 4th 1733."c That same year, on 5 February, there was entered in the Kirkcaldy Council Records an account of "The Method of Teaching and regulations thereannent to be observed in the town." This provides us with information about Miller's curriculum and 
some insight into his method of teaching. The four highest classes were devoted to learning Latin, the fifth to acquiring the ability to read Latin and to cover the grammar of that language--the rudiments--and the sixth class, the "Lectors," to reading English, writing, and arithmetic. 3 The antecedents of this scheme take us to the adaptation by the German Protestant reformers of the Humanists' schemes ${ }_{4}$ for the teaching of rhetoric, in the interest of an individualistic piety.

Miller's pupils in the highest or first class were required to do homework nightly in the form of a passage of translation "to Exercise their Judgements to teach them by degrees to spell rightly to write good wryte [i.e., style] Good sense and Good Languadge." The translations were examined after the morning assembly, and then the boys were required to translate back into Latin from the English, sticking to the "naturall and Constituted order of the [Latin] words." Later in the morning, the first and second classes had to write a theme while the third and fourth classes were going over Latin grammar, the fifth one was reading English, and the sixth class was reading or writing English or being taught arithmetic. At this period also the fifth and sixth classes were put through questions in the Catechisms. Piety was clearly still importnt, but the pressure felt in the sixteenth century to acquire a distinguished Latin style at school had lessened, because it was no longer the language of affairs. The rhetorical training was directed at expressiveness in English, though its effectiveness was appreciated as a means of entry into the classics.

Smith's Eutropius would come into use in the fifth and fourth classes to assist mastery of the rudiments of Latin and to enlarge vocabulary, and also to provide a conspectus of Roman history from the founding of the city to the death of the Emperor Jovian in A.D. 364. The second surviving school text was another historical work, embracing Universal History this time: Justinus' third-century A.D. epitome of the Historiae Philippicae by the Augustan writer Pompeius Trogus, which covers the Ancient Orient and Greece as well as Rome. 5 These works constituted a storehouse of episodes and anecdotes to be turned to rhetorical use--"to point a moral, or adorn a tale"--and were approached by schoolmasters in that spirit. Smith may have obtained much more from them, a lifelong interest in history, for example, which adds so much depth to his theoretical work in social science.

Modern scholarship finds the qualities of "impartiality" and "good judgment" in Eutropius, 6 but a view given wide currency in Smith's time was that it offered "a very lifeless abridgment of the Roman history, generally full of a great number of proper names, and chronological dates, which are apt to discourage children upon their first entrance on the study of Latin."7 Thus Charles Rollin, classicist and historian, who drew on his teaching experience as a professor of eloquence or rhetoric at the University of Paris and teaching practice in French schools, in a series of treaties entitled De la Manière d'Enseigner et d'Etudier les Belles Lettres, par rapport à l'esprit et au coeur (Paris, 1726-28). This was translated into English and published at London in March 1734. By 1759 it had reached a fifth edition of the English translation published at Edinburgh, entitled The Method of Teaching and Studying the Belles Lettres, or, An Introduction to Languages, Poetry, Rhetoric, History, Moral Philosophy, 
Physics, \&c. with Reflections on Taste, and Instructions with Regard to the Eloquence of the Pulpit, the Bar, and the Stage. The whole illustrated with Passages from the most famous Poets and Orators, ancient and modern, with critical Remarks on them. Designed more particularly for Students in the Universities. In its fulsome way, this title indicates the tradition in which Smith was educated and which he furthered by his own teaching of rhetoric and the belles lettres, the latter phrase apparently introduced into English by Rollin's work. 8 Rollin lays out a curriculum for the "attainment of the Latin tongue" much like that of Miller in Kirkcaldy, involving "the explaining of authors, the making of exercises, and translation." Justinus turns up in his list of authors for the fourth class, together with "Caesar's commentaries, Terence's comedies, [and] some discourses and epistles of Tully [i.e., Cicero]." 9 These authors in selected portions would be familiar to Smith, and the mention of Terence in this context brings to mind Miller's initiative in bringing in drama or at least oratory to enliven his teaching or perhaps to round off the teaching year. He wrote a piece entitled "A Royal Council for Advice, or the Regular Education of Boys the Foundation of all other Improvements" for presentation in August 1734. In this piece, which was said to have given high satisfaction to the audience,

the council consisted of a preses and twelve members, decently and gravely seated round a table like senators; the other boys were posted at a due distance in a crowd, representing people coming to attend this meeting for advice; from whom entered, in their turn and order, a tradesman, a farmer, a country gentleman, a nobleman, two schoolmasters, etc., and last of all a gentleman who complimented and congrafulated the council on their noble design and worthy performance.

One longs to know what role, if any, was assigned to the eleven-yearold Adam Smith--principal or sweller of the crowd--but these and other efforts by Miller made Smith a good scholar, well grounded in Latin and with a beginning in Greek, so that when he went to Glasgow University for the Martinmas Term of 1737, he entered the third class devoted to Logic. We find an account of the Glasgow Arts curriculum of the time in Chamberlayne's Magnae Britanniae Notitia for 1737, and it has the provision that "all who have studied well the Latin Tongue at School, and have got the Rudiments of the Greek are admitted to enter as of the Bajan Class; nay, may enter the Logick Class."ll The Logic Chair was occupied by a veteran Professor, John Loudoun, who had been a Regent under the old system of dictates and tutorials superseded by a professorial and lecture system in 1727. Sets of dictates and lecture notes in Latin from his classes have survived, 12 and there is the evidence of the recollection of Smollett who took the Logic class about Smith's time, all suggesting, as Smollett put it, that the students "learned [ about] Aristotle's Categories, and the opposition and conversion of propositions.... The art of logic has been transformed into a kind of legerdemain, by which boys can syllogize." 13

This fare was not greatly to Smith's taste. At least, we presume so, because in due course when he occupied Loudoun's Chair he provided something radically different. To be sure, logic was traditionally the copartner with grammar and logic in the medieval Trivium of the first stage 
of university education, and when Petrus Ramus reorganised the curriculum in the sixteenth century, he allocated the rhetorical topics of "invention" and "disposition" to logic. 14 It is likely that Smith would be required to demonstrate familiarity with these topics in the required Latin disputations on logical questions of the semi-class exercises, and in the formal Latin oration which every student was obliged to recite before the Logic Professor every year.15 In addition to work in logic, Smith seems to have read Greek in his first year under the direction of Professor Alexander Dunlop, who had written a highly-regarded Greek grammar (1736). As evidence of Smith's studies we have his copy of the Encheiridion of Epictetus, 16 literally a Handbook, dealing with Stoic philosophy, emphasising the doctrine of the freedom of the mind and will so congenial to Smith. Under Dunlop, students also studied such books as Aristotle's Poetics and the treatise On the Sublime ascribed to Longinus. Alexander "Jupiter" Carlyle, who was at Glasgow three years after Smith left (c. 1743), recorded in his Autobiography that he "Deriv'd much pleasure, as well as Enlargement of Skill in the Greek Language, from Mr. Dunlop's Translations and Criticisms of the Great Tragick Writers in that Language."17 Thus it is possible that Adam Smith owed his introduction to criticism in the belles-lettres tradition to Dunlop.

His proficiency in Greek was needed to advance in the second or third year at Glasgow University to the Moral Philosophy class of Francis Hutcheson, whom late in life Smith distinguished as "never to be forgotten."l8 Hutcheson gave his students an account of the "Passions and Virtues" in striking terms, and Carlyle remembered that when "the Subject Led him to Explain and Inforce the Moral Virtues and Duties, he Display'd a fervent and Persuasive Eloquence which was Irresistable."19 At one point Mathematics and Natural Philosophy were regarded by Smith as his favourite subjects at Glasgow, 20 but his career attests that it was Moral Philosophy as expounded by Hutcheson that made the deepest impact; and, it is argued here, mastery of rhetorical principles embracing composition and criticism beckoned as the gateway to advance in the science of human systems and values. Such an association of these disciplines of the mind was a long-established tradition, as is noted in a comment on the favourite studies of Coluccio Salutati, chancellor of Florence c. 1400: "the first expression of humanism appeared in oratory, loqic, and rhetoric, and, in conjunction with these, in morals and politics."

From Glasgow, Smith went to Balliol College as a Snell Exhibitioner in 1740. It was a time of intellectual torpor at Oxford, with Balliol even below par for the University, and its Master, Dr. Theophilus Leigh, taking a lead in showing prejudice against the Scotsmen on the Snell foundation. 22 Smith wrote to his guardian that "it will be his own fault if anyone should endanger his health at Oxford by excessive Study, our only business here being to go to prayers twice a day, and to lecture twice a week."23 On his own Smith read Hume's Treatise of Human Nature, for which act of intellectual defiance he is said to have been chastised by the heads of his College, 24 and he devoted a considerable amount of time to the "practice of translation (particularly from the French), with a view to the improvement of his own style."25 He also studied classical Greek and Latin and the modern languages of French, Italian, and English, and 
read extensively in the poetry of these languages. In short, he was further preparing himself for reformulating the principles of rhetoric in the light of the needs of his contemporaries. At the same time, his approach to the study of the belles-lettres is in the tradition of such writers as Rollin who, for example, had specifically counselled that giving youth the most beautiful passages of authors to translate "is the surest way of forming their taste. They will thereby become acquainted with their authors, and insensibly conceive their height of fancy, manner of writing, and way of thinking." 26 Rollin's more general claim, of course, is that taste "is a kind of natural reason wrought up to perfection by study," and that though good taste may be formed by literary studies, most appropriately so at the outset of life,

\begin{abstract}
it is not confined to literature; it takes in also . . all arts and sciences, and branches of knowledge. It consists therefore in a certain just and exact discernment, which points out to us in each of these sciences and branches of knowledge, whatever is most curious, beautiful and useful, whatever is most essential, suitable, or necessary to those who apply to it; how far consequently we should carry the study of it; what ought to be removed from it; what deserves a particular application and preference before the rest. For want of this discernment, a man may fall short of the most essential part of his profession, without perceiving it; nor is the case so rare as one might imagine.
\end{abstract}

It was thinking along this line that afforded Smith an opportunity to become a lecturer on rhetoric and belles-lettres during the next stage in his career. He left Oxford to return to Kirkcaldy in 1746, apparently unwilling to make a career in the Church of England as had been envisaged for Snell Exhibitioners. Two years later, becoming aware of the young man's literary attainments, Henry Home of Kames, a leading advocate and archmover of progressive enterprises in Scotland, sponsored a series of lectures by Smith on rhetoric and belles-lettres. This sponsorship was shared by another advocate, Robert Craigie of Glendoick, who was related to Smith on his mother's side, and the M.P. for Kirkcaldy, James Oswald of Dunnikier. 28 This series was given in Edinburgh, and it was primarily intended to add to the professional attainments of young ministers and lawyers. One witness writing after 1776 reported that Smith gave

a set of admirable lectures of languge (not as a grammarian but as a rhetorician) on the different kinds or characteristics of style suited to different subjects, simple, nervous, etc., the structure, the natural order, the proper arrangement of the different members of the sentence etc. He characterised the style and genius of some of the best of the ancient writers and poets, but especially historians, Thucydides, Polybius etc. translating long passages from them, also the style of the best English classics, Lord Clarendon, Addison, Swift, Pope, etc. . . His remarks and rules given in the lectures I speak of, were the result of a fine taste and sound judgement, well suited to be exceedingly useful to young composers, so that I have often regretted that some part of them has never been published. 29 
The lectures were well received, so much so that they were repeated in 1749-50. Smith cleared 100 pounds a year from them, and from a third set of lectures in 1750-51 devoted to the rise of jurisprudence in a historical context.30 Both sets of lectures were influential. One auditor, Hugh Blair, borrowed the rhetoric set, and used them for elaborating his own similar series which brought him a Chair in Rhetoric and Belles Lettres at Edinburgh University in 1762.31 Another auditor, William Robertson, is said to have responded to the second set by making them a basis for the "view of the progress of society with respect to government, laws and manners" which prefaced his History of the Reign of the Emperor Charles V (1769).32 Smith's reputation was such that he was elected unanimously in January 1751 to the Chair of Logic at Glasgow left vacant by Loudoun's death on 1 November 1750.

Because of his lecturing commitment in Edinburgh, Smith could not go to Glasgow until October 175l, but at that time Thomas Craigie, successor to Francis Hutcheson in the Moral Philosophy Chair, had fallen ill, and his classes had to be divided between Smith and three other Professors. 33 In tackling the new duties that crowded in on him, Smith displayed his abilities as an innovator while acknowledging the central importance of rhetoric and literary criticism for higher education. We have a report of his procedures from John Millar, who had attended his Edinburgh lectures, and who later became his colleague at Glasgow University:

In the Professorship of Logic, to which Mr Smith was appointed on his first introduction to this University, he soon saw the necessity of departing widely from the plan that had been followed by his predecessors, and of directing the attention of his pupils to studies of a more interesting and useful nature than the logic and metaphysics of the schools. Accordingly, after exhibiting a general view of the powers of the mind, and explaining so much of the ancient logic as was requisite to gratify curiosity with respect to an artificial method of reasoning, which had once occupied the attention of the learned, 34 he dedicated all the rest of his time to the delivery of a system of rhetoric and belles lettres. The best method of explaining and illustrating the various powers of the human mind, the most useful part of metaphysics, arises from an examination of the several ways of communicating our thoughts by speech, and from an attention to the principles of those literary compositions which contribute to persuasion or entertainment. By these arts, everything that we perceive or feel, every operation of our minds, is expressed and delineated in such a manner, that it may be clearly distinguished and remembered. There is, at the same time, no branch of literature more suited to youth at their first entrance upon 35 philosophy than this, which lays hold of their taste and feelings. 35

Millar expressed regret that the manuscript containing Smith's lectures on rhetoric and belles-lettres was destroyed before his death; it was, in fact, burnt by Joseph Black and James Hutton acting on Smith's command as his literary executors.36 In 1958, however, Professor John Lothian of Aberdeen University acquired from sales of books and papers from the library of the Forbes-Leith family of Whitehaugh two slim manuscript volumes 
bearing on their spines the inscription, 'Notes of Dr. Smith's Rhethorick Lectures.' These proved to be a student's copy of lecture notes for $37^{\text {se- }}$ ries dated from Friday 19 November 1762 until Friday 18 February 1763. ${ }^{3}$

This fortunate discovery lacks the first lecture, but the remaining twenty-nine fall into the two major divisions suggested by Millar's account: first, "an examination of the several ways of communicating our thoughts by speech" (lectures 2 through 11); and, second, "an attention to the principles of those literary compositions which contribute to persuasion or entertainment" (12 through 30). That Smith's rhetoric is a system of a piece with his ethical thinking, for example, is made clear in the sixth lecture in which he challenges the standpoint of traditional rhetoric that the expressive force and beauty of language reside in figure of speech. Smith's claim is that

when the sentiment of the speaker is expressed in a neat, clear, plain, and clever manner, and the passion or affection he is poss[ess]ed of and intends, by sympathy, to communicate to his hearer, is plainly and cleverly hit off, then and then only the expression has all the force and beauty that language can give it.

Because the "grammarians" are confused about the role of figures of speech and do not appreciate the fact that, for example, the beauty of a passage "flows from the sentiment and the method of expressing it being suitable to the passion," they form their systems of rhetoric "from the consideration of these figures [of speech], and divisions and sub-divisions of them." With some asperity, Smith concludes, "38 they are generally a very silly set of books and not at all instructive." 3

Smith seeks to be instructive in the first division of his lectures by emphasising that

the perfection of style consists in express[ing] in the most concise, proper, and precise manner the thought of the author, and that in the manner which best conveys the sentiment, passion, or affection with which it affects--or he pretends it does affect--him, and which he designs to communicate to his reader.

Smith concedes that this is but "common sense," and points out that

all the rules of criticism and morality, when traced to their foundation, turn out to be some principles of common sense which every one assents to: all the business of those arts is to apply these rules to the different subjects, and shew what the conclusion is when they are so applied. 39

We are not very far here from Rollin's concept of a universal "good taste," which he considered was not "confined to literature" but "takes in also... all arts and sciences, and branches of knowledge." Smith reinforced his teaching about the efficacy of the plain style by contrasting the precision and nervousness of Swift with the floridity of Shaftesbury. 
When he turned, second, to the "principles of those literary compositions which contribute to persuasion or entertainment," Smith of fered a shrewd analysis with well-chosen illustrations of the following forms of discourse: narrative, i.e., historical and poetical (epic) writing; didactic, i.e., philosophic and scientific writing; and rhetorical or oratorical, i.e., deliberative, forensic, and demonstrative eloquence. $\overline{\text { Further }}$ elements of Smith's characteristic thought appear in this division, for example, the importance of the pleasure principle with reference to didactic composition. He notes in distinguishing between the Newtonian and Aristotelian systems of science that

it gives us a pleasure to see the phenomena which we reckon the most unaccountable, all deduced from some principle (commonly, a wellknown one) and all united in one chain, far superior to what we feel from the unconnected method, where everything is accounted for by itself, without any reference to others. 40

Elsewhere, he comments on the fact that as societies become commercial and opulent, prose is cultivated, since it is "naturally the language of business, as poetry is of pleasure and amusement; "4I and he displays awareness of cultural relativism, reporting that Athenian oratory designed for a demperacy would not have suited Rome with its patrician order of government.

The date of the delivery of these rhetoric lectures, 1762-63, indicates that they fell into the period when Smith occupied the Chair of Moral Philosophy, and it appears auditors believed they could be usefully associated with his concomitant investigation of the divisions of moral science, which for Smith principally included ethics, jurisprudence, and political economy. 43 Smith's successor in the Chair of Logic, James Clow, reverted to the traditional approach of Loudoun to teaching that subject, but he did maintain Smith's innovation of lecturing in English. Clow's successor, however, George Jardine, was one of Smith's favourite pupils in the 1760s, with some experience of a wider intellectual world as tutor to the sons of Mure of Caldwell in Paris, where he had introductions through David Hume to such eminent philosophes as Helvétius and D'Alembert. 44 Jardine came to feel that the traditonal approach to logic in the first philosophy class was a barren one, inappropriate to the needs of the students. Accordingly, he reorganized the curriculum very much along the lines of Smith's system as described in Millar's account quoted earlier in this paper. Jardine's scheme is presented most fully in the second edition of Outlines of Philosophical Education, illustrated by the Method of Teaching the Logic Class in the University of Glasgow (Glasgow, 1825). Its summary of subjects covered in the first philosophy class may be quoted as evidence that Jardine was the true inheritor of the legacy of the reformulation of rhetoric, and its integration into university studies, that Smith bequeathed to Glasgow:

1st. The elements of the science of mind, or, an analysis of the powers of the mind, particularly of those by which knowledge is acquired, followed by an illustration of their several modes of operation, derived from the origin of language, and the principles of general grammar. 
2d. The elements of intellectual culture, applied to each respective faculty, and to their mutual co-operation or processes of action: illustrated by the history of logic, ancient and modern. 3d. An analysis of the powers of taste; or, as they are sometimes called, of the internal or reflex senses, of novelty, beauty, sublimity, \&c.

4th. An explanation of the means by which these powers or susceptibilities are cultivated; illustrated by the history of the fine arts, and the principles of composition in the department of belles lettres.

5th. The powers of communication by speech and writing; and the means of cultivating these powers, illustrated by the history of the arts of rhetoric and criticism.

These subjects may be supposed to occupy a third or a fourth part of the under-graduate course, and are very properly made to precede the more profound inquiries which belong to ethics and physics (pp. 422-23).

There remains, finally, the task of demonstrating that, as was claimed at the outset of this paper, Smith put rhetoric to use successfully in the composition of The Theory of Moral Sentiments and An Inquiry into the Nature and Causes of the Wealth of Nations. In these books, Smith is essentially presenting himself as a system-builder, and the appropriate type of discourse for this function is what he called didactic. His chief theoretical point about didactic discourse is that two methods were available for this: the Aristotelian, in which "we begin by saying we are to explain such and such things, and for each advance a principle either different or the same with those which went before"; and the Newtonian, in which "we lay down one or very few principles by which we explain the several rules of phenomena, connecting one with the other in a natural order." "In every science," Smith continues, "whether of morals or natural philosophy," the later method is vastly more ingenious. 45 And ingenious Smith certainly is in developing on the Newtonian model, first, a system of morals from the principles of sympathy and, second, an economic system from the principles of the natural propensities to better one's condition and to truck, barter, and exchange. 46 That the success of TMS was due to "powerful reasoning" and to its artful composition and style was allowed by Edmund Burke, no mean judge of such matters. 47 As for WN, while the ascription to Smith of originality with respect to component analytic ideas has been challenged, 48 his rhetorical superiority in that book over contemporary writers on economic subjects such as Sir James Stewart and Quesnai and Turgot as synthesizer and exponent of a new social science is readily apparent. 49 "Before Smith there was economic discussion," 50 runs a modern

But the rhetorical situation for Smith is complicated by the fact that there is a historical dimension to his writing. He was a leading contributor to the stage of the Scottish Enlightenment which inspired Hume to declare, "I believe this is the historical Age and this the historical Nation."51 Thus, the sentiments or feelings concerning which Smith theorizes in his ethical book are discussed as arising from changing historical circumstances, and he brings out the noteworthy point that the content of moral rules varies with the stage of society. In pastoral 
communities, he suggests, kinship bonds dictate behaviour regarded as moral to a degree not found in commercial societies which, in their turn, esteem benevolence in a fashion not found in primitive societies. 52 Taking a similar "Conjectural History" approach, but pressing it with greater narrative force, Smith charts in his book on political economy the emergence of the commercial society of his time, seeking to lay bare the complex processes of history by relating "events and connecting them with their causes without becoming ${ }_{33}$ party on either side" in the spirit of such a historian as Machiavelli.

A further complication, still, in the rhetorical situation confronted by Smith was the fact that first and last he was a moralist. He gave his declining years to the refinement of The Theory of Moral Sentiments rather than to the Wealth of Nations, and among the additions to the first book for the sixth edition of 1790 was a new part (VI) which included eloquent descriptions of the model wise and virtuous man. Yet, as has been well said, the part of Wealth of Nations dealing with mercantilist colonial power is an "essay in persuasion,"54 and to a degree this and similar parts are rhetorical or oratorical discourses, persuading the reader of the enormity of mercantilism and the exercise of colonial power, and the value of the system of natural liberty in the economic as in the political order, just as vice is condemned and virtue praised in The Theory of Moral Sentiments. Amidst these rhetorical complexities, true to hs own ideal, Smith is the master of that perspicuous and plain style so effective in gaining the attention of the world of everyday affairs as well as the world of learning. Consider his penetrating comment about the mischief caused by status-seeking--"Place, that great object which divides the wives of aldermen, is the end of half the labours of human life; and is the cause of all the tumult and bustle, all the rapine and injustice, which averice and ambition have introduced into this world" (TMS I.iii.2.8); or, again, there is his disabused view of the human selfishness that brought about the decay of feudal lordship, once commerce and manufactures provided objects for the exercise of that selfishness: "All for ourselves, and nothing for other people, seems, in every age of the world, to have been the vile maxim of the masters of mankind" (WN III.iv.10).

Rhetoric, then, for Smith, is what the Ruskin Index said it is--"a base subject"--but not in the Ruskinian sense of debased, rather that of a foundation subject, a general theory of discourse, capable of sustaining analysis with respect to particular applications in modes of crucial importance to a thinker like Smith: systematic exposition, narrative historical discourse with a "conjectural" element, and moral suasion. Above all, for Smith, rhetoric is a study for those who wish to be undeceived. 
NOTES

Dugald Stewart, "Account of the Life and Writings of Adam Smith, L.L.D.," I.4, printed with Adam Smith, Essays on Philosophical Subjects, ed. W.P.D. Wightman, J.C. Bryce, and I.S. Ross (Oxford: Clarendon Press, 1980); references to Stewart's memoir and to Smith's writings conform to the system used in the Glasgow Edition of the Works and Correspondance of Adam Smith (Oxford: Clarendon Press, 1976-). Corr. = Correspondance; EPS = Essays on Philosophical Subjects; TMS = Theory of Moral Sentiments; and WN = Wealth of Nations.

James Bonar, A Catalogue of the Library of Adam Smith, 2nd ed. (London: Macmillan, 1932), p. 67; the book is in the Adam Smith Collection at Kirkcaldy Museum.

Kirkcaldy Council Records 1718-1746, 1/1/3, ff. 299-300.

R.R. Bolgar, The Classical Heritage and Its Beneficiaries (Cambridge: Cambridge University Press pb., 1977 rpt.), pp. 342-56.

Murray C.T. Simpson, "Books Belonging to Adam Smith in Edinburgh University Library: A Survey of Newly Discovered Items," The Bibliotheck, 9 (1979), 191.

A.H. McDonald, "Eutropius," The Oxford Classical Dictionary, 2nd ed. (1978 rpt.).

Charles Rollin, The Method of Teaching and Studying the Belles Lettres, 5th ed., I (Edinburgh: A. Kincaid et al., 1759), 169.

Wilbur Samuel Howell, Eighteenth-Century British Logic and Rhetoric (Princeton: Princeton University Press, 1971), pp. 532-33.

Rollin, I (1759), 169, 182.

10 James Grant, History of the Burgh Schools of Scotland (London and Glasgow: W. Collins, 1876), p. 414.

11 Edward Chamberlayne, Magnae Britanniae Notitia, ed. John Chamberlayne, 33rd ed. of England, 12th of Scotland (London, 1737), Pt. II, Book III, University of Glasgow, 13.

12 Glasgow University Library, Special Collections: for 1690--MS Murray 225; 1699--MS Murray 49; 1712--MS Gen. 406; 1714-15--MS Gen. 71; 1729--MS Murray 210.

13 Extract from Critical Review, XI (March, 1761), 225-26, quoted in Lewis Mansfield Knapp, Tobias Smollett: Doctor of Men and Manners (Princeton: Princeton University Press, 1949), p. 16, n. 50. 
14 Howell, Logic and Rhetoric in England, 1500-1700 (Princeton: Princeton University Press, 1956), pp. 299-309; Howell, Eighteenth-Century British Logic and Rhetoric, p. 16; Peter France, Rhetoric and Truth in France: Descartes to Diderot (Oxford: Clarendon Press, 1972), p. 16.

Chamberlayne, Pt. II, Book III, 441.

Bonar, 65-66; William Robert Scott, Adam Smith as Student and Professor, Glasgow University Publications XLVI (Glasgow: Jackson, Son \& Co., 1937), pp. 33-34.

17 Alexander Carlyle, Anecdotes and Characters of the Times, ed. with an introduction by James Kinsley (London: Oxford University Press, 1973), p. 37.

18 Corr. No. 274, letter of 16 Nov. 1787 from Smith, accepting election as Rector of Glasgow University.

Carlyle, p. 36.

Stewart, I.7.

21 Eugenio Garin, Portraits from the Quattrocento, trans. Victor A. and Elizabeth Velen (New York: Harper \& Row pb., 1972), p. 3.

H.W. Carless Davis, A History of Balliol College, rev. R.H.C. Davis and Harold Hunt (Oxford: Basil Blackwell, 1963), pp. 154-56, 164.

Corr. No. 1, letter dated 24 August 1740.

J.R. McCulloch, Sketch of the Life and Writings of Adam Smith, LL.D. (Edinburgh: priv. ptd. 1855), p. 8. McCulloch states (n. 1), "Stewart has not mentioned this circumstance, but it rests on the best authority."

Stewart, I.9.

Rollin, I (1759), 93.

Rollin, I (1759), 61.

Scott, pp. 46-48.

James Wodrow's account, quoted in Scott, pp. 51-52.

Corr. No. 25, letter from Hume, 8 June 1758.

John Rae, Life of Adam Smith [1895], intro. by Jacob Viner (New York: Augustus M. Kelley, 1965), pp. 32-33; Scott, pp. 48, 52 .

Scott, pp. 50-51, 55-57. 
Scott, p. 66 .

34 This part of Smith's course is probably represented by "The Principles which lead and direct Philosophical Enquiries; illustrated by the History of the Ancient Logics and Metaphysics" in EPS.

Stewart, I.16.

Stewart, V.8; Rae, p. 434.

37 John M. Lothian, ed. with intro., Lectures on Rhetoric and Belles Lettres.. . by Adam Smith (Edinburgh: Nelson, 1963), p. xi (references are to this ed.); the fullest account of the nature of LRBL is given in Wilbur Samuel Howell, Eighteenth-Century British Logic and Rhetoric, pp. 536-37; but see the critical rev. by Brian Vickers, TLS, 5 August 1977, p. 965.

38 Lecture 6, Mon. 29 Nov. 1762, pp. 22-23.

39 Lecture 11, Wed. 15 Dec. 1762, p. 51.

40 Lecture 24, Mon. 24 Jan. 1763, pp. 139-40.

41 Lecture 23, Fri. 21 Jan. 1763, p. 132.

42 Lecture 26, Mon. 31 Jan. 1763, pp. 152-53.

43 James Boswel, for example, attending Glasgow University in 1759-60 as a kind of post-graduate student from Edinburgh, took Smith's courses on Moral Philosophy and Rhetoric, the latter probably a private one; see F.A. Pottle, "Boswell's University Education," Johnson, Boswell and their Circle: Essays Presented to L.F. Powell (Oxford: Clarendon Press, 1965), p. 247, n. 1.

44 James Coutts, A History of the University of Glasgow (Glasgow: James Maclehose and Sons, 1909), p. 312.

45 Lecture 24, p. 140.

46 T.D. Campbell, Adam Smith's Science of Morals (London: George Allen and Unwin Ltd., 1971), p. 31, considers that Smith aimed at the "Newtonian method" in TMS, but that WN "is nearer to the alternative ['Aristotelian'] method." Immediately on its publication, however, WN had been perceived by Governor Thomas Pownall as following the Newtonian model, giving him "a compleat idea of that system . . . that might fix some first principles in the most important of Sciences, the knowledge of the human community, and its operations. That might become principia to the knowledge of politick operations; as Mathematicks are to Mechanicks, Astronomy, and the other Sciences" (Corr., p. 337: Appendix A, letter from Pownall, 25 Sept. 1776). 
48 J.A. Schumpeter, History of Economic Analysis (New York: Oxford University Press, 1954), p. 184, quoted in David W. Pearce ed., The Dictionary of Modern Economics (London: Macmillan, 1981), p. 396.

49 See the adverse comments on the style and organization of these authors as follows: Andrew Skinner, ed. with intro., Sir James Stewart, An Inquiry into the Principles of Political Economy, I (Edinburgh: Oliver \& Boyd, 1966), Iviii-lx; Ronald L. Meek, The Economics of Physiocracy (London: George Allen \& Unwin Ltd., 1962), p. 39; Ronald L. Meek, trans., ed., and intro., Turgot on Progress, Sociology and Economics (Cambridge: Cambridge University Press, 1973), p. 34 .

50 Pearce ed., The Dictionary of Modern Economics, p. 396.

51 The Letters of David Hume, ed. J.Y.T. Greig, II (Oxford: Clarendon Press, 1969 rpt.), 230 .

52 TMS Vl.ii.1.12-13; the approach was called "Theoretical or Conjectural History" by Stewart--see his "Account of Smith," II. 44-56, which deals with a dissertation probably associated with the teaching of rhetoric: "Considerations Concerning the First Formation of Languages" (Philological Miscellany, 1761; TMS ed. 3, 1767).

53 Lecture 20, Wed. 12 Jan., p. 111.

54 Andrew Skinner, A System of Social Science: Papers Relating to Adam Smith (Oxford: Clarendon Press, 1979), p. 185. 